\title{
Effects of ginger and its pungent constituents on transient receptor potential channels
}

\author{
YOUNG-SOO KIM ${ }^{1}$, CHANSIK HONG ${ }^{2}$, SANG WEON LEE ${ }^{1}$, JOO HYUN NAM ${ }^{3,4}$ and BYUNG JOO KIM ${ }^{5,6}$ \\ ${ }^{1}$ Department of Neurosurgery, College of Medicine, Pusan National University, Yangsan Hospital, Yangsan; \\ ${ }^{2}$ Department of Physiology and Biophysics, Seoul National University College of Medicine, Seoul; ${ }^{3}$ Department of Physiology, \\ Dongguk University, College of Medicine, Kyungju; ${ }^{4}$ Channelopathy Research Center (CRC), Dongguk University \\ College of Medicine, Goyang; ${ }^{5}$ Healthy Aging Korean Medical Research Center (HAKMRC) and ${ }^{6}$ Division of Longevity \\ and Biofunctional Medicine, Pusan National University, School of Korean Medicine, Yangsan, Republic of Korea
}

Received November 18, 2015; Accepted October 24, 2016

DOI: $10.3892 /$ ijmm.2016.2791

\begin{abstract}
Ginger extract is used as an analeptic in herbal medicine and has been reported to exert antioxidant effects. Transient receptor potential (TRP) canonical 5 (TRPC5), TRP cation channel, subfamily M, member 7 (TRPM7; melastatin 7), and TRP cation channel, subfamily A, member 1 (TRPA1; ankyrin 1) are non-selective cation channels that are modulated by reactive oxygen/nitrogen species (ROS/RNS) and subsequently control various cellular processes. The aim of this study was to evaluate whether ginger and its pungent constituents modulate these channels and exert antioxidant effects. It was found that TRPC5 and TRPA1 currents were modulated by ginger extract and by its pungent constituents, [6]-gingerol, zingerone and [6]-shogaol. In particular, [6]-shogaol markedly and dose-dependently inhibited TRPC5 currents with an $\mathrm{IC}_{50}$ of value of $\sim 18.3 \mu \mathrm{M}$. Furthermore, the strong dose-dependent activation of TRPA1 currents by [6]-shogaol was abolished by A-967079 (a selective TRPA1 inhibitor). However, ginger extract and its pungent constituents had no effect on TRPM7 currents. These results suggest the antioxidant effects of ginger extract and its pungent constituents are mediated through TRPC5 and TRPA1, and that [6]-shogaol is predominantly responsible for the regulation of TRPC5 and TRPA1 currents by ginger extract.
\end{abstract}

Correspondence to: Professor Joo Hyun Nam, Department of Physiology, Dongguk University, College of Medicine, Dongguk University, 123 Dongdaero, Kyungju 38066, Republic of Korea E-mail: jhnam@dongguk.ac.kr

Professor Byung Joo Kim, Division of Longevity and Biofunctional Medicine, Pusan National University, School of Korean Medicine, 49 Busandaehakro, Mulgeum-eup, Yangsan, Gyeongsangnamdo 50612, Republic of Korea

E-mail: vision@pusan.ac.kr

Key words: ginger extract, [6]-gingerol, zingerone, [6]-shogaol, transient receptor potential canonical 5 , transient receptor potential cation channel, subfamily A, member 1

\section{Introduction}

In central nervous system (CNS) neurons, calcium metabolism, cell energy metabolism secondary to altered cerebral blood flow, mitochondrial content and oxidative metabolism play important roles in the regulation of the neurological status at the cellular and organismal levels (1). Furthermore, age-related impairments ultimately converge to negatively impact cell respiration, which manifests as the overproduction of reactive oxygen species (ROS). Oxidative stress is defined as an imbalance between the production of ROS or reactive nitrogen species (RNS) and the production of antioxidants (2). For this reason, oxidative stress has become the one of the main targets for the treatment of neurological diseases (3).

Ginger (the rhizome of Zingiber officinale) is a popular spice and food supplement, and has been reputed to have medicinal effects for centuries $(4,5)$. Ginger extract is still used traditionally as an herbal medicine due to its analeptic properties, which include antioxidant, anti-lipidemic, anti-microbial, antiinflammatory, anti-hyperglycemic, anti-emetic and anticancer effects (6-8). The pungent phytochemicals of ginger consist of [6]-gingerols, zingerone, and [6]-shogaols and these constituents have also been reported to be responsible for most of its pharmacological effects $(9,10)$. Many researchers have studied the antioxidant properties of ginger. It has been reported to exert antioxidant protective effects against $\mathrm{Pb}$-induced hepatotoxicity (11), and to exert significant beneficial effects on sperm viability, motility and serum total testosterone levels due to its antioxidant effects (12). [6]-Shogaol is a novel small molecule activator of nuclear factor (erythroid-derived 2)-like 2 (Nrf2) in PC12 cells, and therefore, it is a potential candidate for the prevention of oxidative stress-mediated neurodegenerative disorders (2). Furthermore, cysteine-conjugated shogaols in ginger have been found to induce apoptosis via an oxidative stress-mediated p53 pathway in human colon cancer cells (13).

Transient receptor potential (TRP) channels were first cloned from Drosophila species and constitute a superfamily of proteins that encode a diverse group of $\mathrm{Ca}^{2+}$-permeable non-selective cation channels (NSCCs) (14). Based on their amino acid sequences, the TRP family can be divided into 7 subfamilies, namely TRPC (canonical), TRPM (melastatin), 
transient receptor potential cation channel, subfamily A, member 1 (TRPA; ankyrin 1), TRPV (vanilloid), TRPP (polycistin), TRPN (NOMP-Chomologues) and TRPML (mucolipin), which are activated by different physical and chemical stimuli (14). In particular, a class of TRP channels has been found to be modulated by ROS/RNS and to control various cellular processes. TRPM2, the first ROS-sensitive TRP channel identified, is activated by $\mathrm{H}_{2} \mathrm{O}_{2}(15)$ and $\mathrm{H}_{2} \mathrm{O}_{2}$-activated $\mathrm{Ca}^{2+}$ influx through TRPM2 mediates several cellular responses, including cell death (15) and chemokine production in monocytes (16). TRPM7 is activated by ROS/RNS and is an essential mediator of anoxic death (17). In addition to TRPM channels, TRPC5 and TRPV1 are also activated by ROS and nitric oxide (NO) (18). The activation of TRPC5 and TRPV1 involves the oxidative modification of free cystein sulfhydryl groups (18), and the activation of the TRPA1 channel has been shown to occur following oxidative cysteine modification by ROS or RNS (19). TRPA1 is also activated by environmental electrophiles and endogenous electrophilic products of oxidative stress $(20,21)$. However, the effects of ginger and its pungent constituents on TRP channels and the modulatory effects of oxidative stress have not yet been fully elucidated. Therefore, in the present study, we investigated the effects of ginger and its pungent constituents (Fig. 1) on TRPC5, TRPM7 and TRPA1 channels.

\section{Materials and methods}

Materials. Ginger extract (W252108), zingerone (W312401), [6]-gingerol (G1046), [6]-shogaol (SMB00311) and all other agents were purchased from Sigma-Aldrich (St. Louis, MO, USA) and dissolved in distilled water or dimethylsulfoxide (DMSO) to produce stock solutions, which were stored at $-20^{\circ} \mathrm{C}$. The final concentrations of DMSO in bath solution were always $<0.1 \%$, and we confirmed that at a concentration below $0.1 \%$ DMSO did not affect the results. Furthermore, the addition of the abovementioned chemicals did not alter bath solution $\mathrm{pH}$ values. A-967079 (Sigma-Aldrich) was dissolved in DMSO to produce a $10 \mathrm{mmol} / 1$ stock solution, which was added to the extracellular bath solution at a final concentration of $10 \mu \mathrm{M}$ on the day of the experiment for $2 \mathrm{~min}$. Both allyl isothiocyanate (AITC) and niflumic acid (both from Sigma-Aldrich) were dissolved in DMSO to produce a $30 \mathrm{mmol} / 1$ stock solution, which was added to the extracellular bath solution at a final concentration of $10 \mu \mathrm{M}$ or $30 \mu \mathrm{M}$ on the day of the experiment for 4-5 min.

Cell culture. 293 cells (ATCC, Manassas, VA, USA) were maintained according to the supplier's recommendations. For transient transfection, the cells were seeded in 12-well plates. 293 cells stably transfected with the mouse TRPC5 (mTRPC5), TRPM7 or human TRPA1 (hTRPA1) expression vectors were maintained in Dulbecco's modified Eagle's medium (DMEM) supplemented with $10 \%$ fetal bovine serum (FBS), $1 \%$ penicillin-streptomycin, $0.02 \%$ hygromycin B (for TRPA1), $5 \mu \mathrm{g} / \mathrm{ml}$ blasticidin (for TRPM7), and $0.4 \mathrm{mg} / \mathrm{ml}$ zeocin (for TRPM7) (all reagents from Life Technologies, Carlsbad, CA, USA) in a humidified $20 \% \mathrm{O}_{2} / 10 \% \mathrm{CO}_{2}$ atmosphere at $37^{\circ} \mathrm{C}$. The cells were sub-cultured every 2-3 days. TRPM7 expression was induced by the addition of $1 \mu \mathrm{g} / \mathrm{ml}$ tetracycline to the culture medium. zingerone<smiles>COc1cc(CCC(C)=O)ccc1O</smiles>

[6]-gingerol

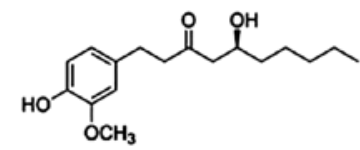

[6]-shogaol

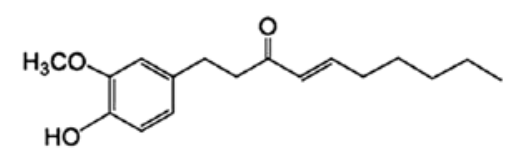

Figure 1. Molecular structure of zingerone, [6]-gingerol and [6]-shogaol.

Transfectionofcellswith TRPC5,TRPM7 andTRPAl expression vectors. For patch clamp experiments, the cells were transferred to $25-\mathrm{cm}^{2}$ cell culture flasks (Life Technologies) 1 day prior to transfection. The 293 cells were transiently transfected with mammalian expression vectors carrying TRPC5 (pcDNA5), TRPA1 (pcDNA5/FRT) or TRPM7 (pCDNA4-TO) (alll vectors were obtained from Thermo Fisher Scientific, Waltham, MA, USA) using Lipofectamine Plus reagent (Life Technologies) according to the manufacturer's instructions. In all transfection experimetns, the 293 cells were co-transfected with the pEGFP-N1 plasmid (from Clontech, Mountain view, CA, USA) to enable visualization. Experiments were performed within 24-36 $\mathrm{h}$ of transfection.

Electrophysiology. The stably 293 cells stably transfected with the TRPC5, TRPM7 or TRPA1 expression vectors were detached from the $25-\mathrm{cm}^{2}$ filtered culture flask by incubation with TrypLE express (Life Technologies) for $2 \mathrm{~min}$. The cells were collected and maintained in a $35-\mathrm{mm}^{2}$ Petri dish (BD Biosciences, Bedford, MA, USA) in DMEM supplemented with $10 \% \mathrm{FBS}$ at $37^{\circ} \mathrm{C}$ and $20 \% \mathrm{O}_{2} / 10 \% \mathrm{CO}_{2}$. An aliquot of cells was allowed to settle in a recording chamber for $5 \mathrm{~min}$ before perfusion was initiated. Whole-cell patch clamp recordings were obtained using an Axopatch 700B amplifier and pClamp v.10.4 software, and signals were digitized at $5 \mathrm{kHz}$ using Digidata 1422A (all from Molecular Devices, Sunnyvale, CA, USA). The RC-13 bath chamber (Warner Instrument, Hamden, CT, USA) containing cells was perfused with an extracellular bath solution composed of TRPC5 [Tyrode's solution: $135 \mathrm{mM} \mathrm{NaCl}, 5 \mathrm{mM} \mathrm{KCl}, 1.8 \mathrm{mM} \mathrm{CaCl}_{2}, 1 \mathrm{mM} \mathrm{MgCl}{ }_{2}$, $5 \mathrm{mM}$ glucose, $10 \mathrm{mM}$ HEPES adjusted to $\mathrm{pH} 7.4$ with $\mathrm{NaOH}$ $\left(\mathrm{Cs}^{+}\right.$-rich external solution was made by replacing $\mathrm{NaCl}$ and $\mathrm{KCl}$ with equimolar $\mathrm{CsCl})$ ], TRPA1 ( $150 \mathrm{mM} \mathrm{NaCl}, 2 \mathrm{mM}$ $\mathrm{CaCl}_{2}, 1 \mathrm{mM} \mathrm{MgCl}, 10 \mathrm{mM}$ HEPES adjusted to $\mathrm{pH} 7.4$ with $\mathrm{NaOH}$ ) and TRPM7 (145 mM NaCl, $2.8 \mathrm{mM} \mathrm{KCl}, 2 \mathrm{mM}$ $\mathrm{CaCl}_{2}, 10 \mathrm{mM}$ glucose, $1.2 \mathrm{mM} \mathrm{MgCl}, 10 \mathrm{mM}$ HEPES adjusted to $\mathrm{pH} 7.4$ with $\mathrm{NaOH}$ ). The pipette solution contained TRPC5 (140 mM CsCl, $10 \mathrm{mM}$ HEPES, $0.5 \mathrm{mM}$ Tris-GTP, $0.5 \mathrm{mM}$ EGTA, $3 \mathrm{mM}$ Mg-ATP adjusted to $\mathrm{pH} 7.3$ with $\mathrm{CsOH}$ ), TRPM7 [145 mM Cs-glutamate, $8 \mathrm{mM} \mathrm{NaCl}, 10 \mathrm{mM}$ Cs-2bis(2-aminophenoxy)-ethane- $N, N, N=, N=$-tetraacetic acid (BAPTA), $10 \mathrm{mM}$ HEPES-CsOH adjusted to $\mathrm{pH} 7.2$ with $\mathrm{CsOH}$ ] and TRPA1 (150 mM CsCl, $1 \mathrm{mM} \mathrm{MgCl}{ }_{2}, 10 \mathrm{mM}$ HEPES, $10 \mathrm{mM}$ BAPTA adjusted to $\mathrm{pH} 7.2$ with $\mathrm{CsOH}$ ). Bath solutions 
A

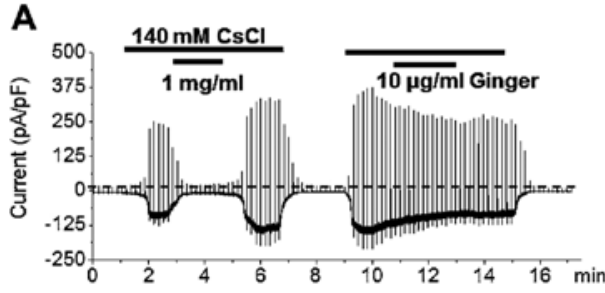

B

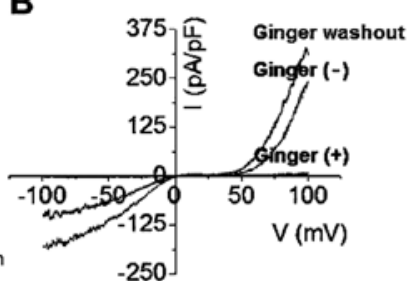

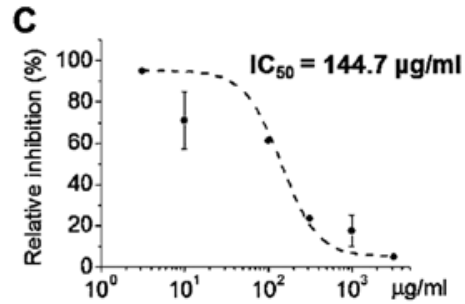

Figure 2. Inhibition of transient receptor potential canonical 5 (TRPC5) by ginger extract. (A) Representative traces showing the $\mathrm{I}_{\mathrm{TRPC}}$ evoked in the presence of $10 \mu \mathrm{g} / \mathrm{ml}$ or $1 \mathrm{mg} / \mathrm{ml}$ ginger extract in 293 cells stably expressing TRPC5. (B) Current-voltage (I-V) curves for control (-) and inhibition of $\mathrm{I}_{\mathrm{TRPC} 5}$ evoked by $1 \mathrm{mg} / \mathrm{ml}$ ginger extract $(+)$. (C) Concentration-dependent inhibition of $\mathrm{I}_{\mathrm{TRPC} 5}$ by ginger extract. The estimated median inhibitory concentration value for ginger extract was $144.7 \mu \mathrm{g} / \mathrm{ml}(\mathrm{n}=7-10 /$ group$)$.
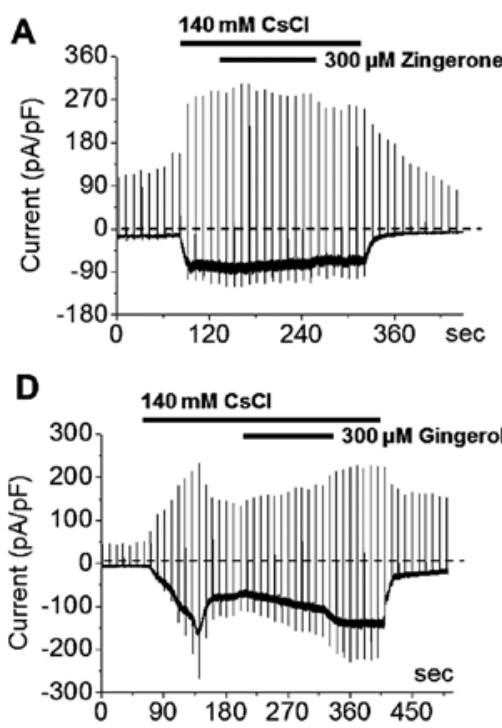

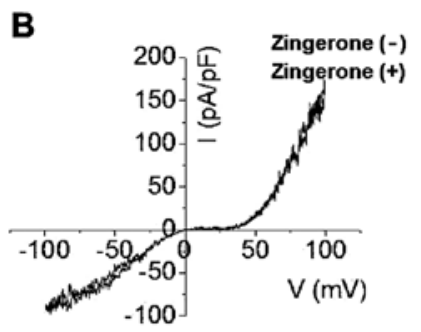

E

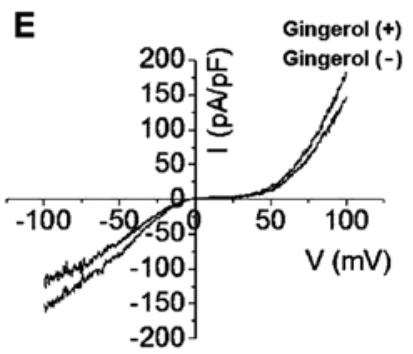

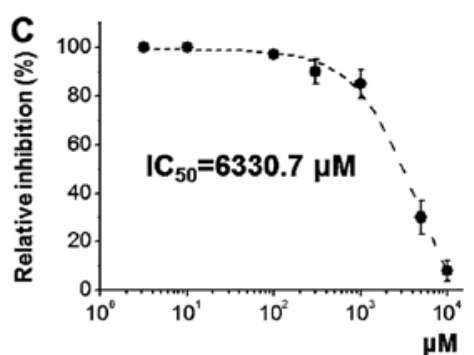

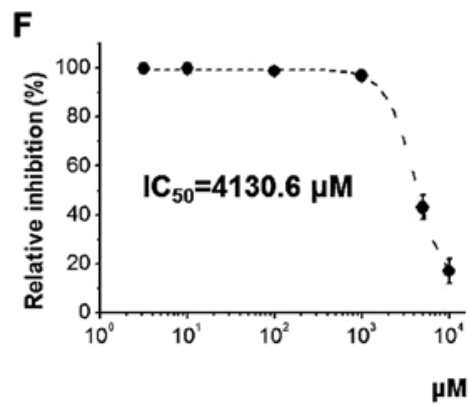

Figure 3. Effect of zingerone and [6]-gingerol on $\mathrm{I}_{\text {TRPC5. }}$. Effect of treatment with (A-C) $300 \mu \mathrm{M}$ zingerone and (D-F) [6]-gingerol on $\mathrm{I}_{\text {TRPC5 }}$ in 293 cells stably expressing transient receptor potential canonical 5 (TRPC5). (A and D) Representative traces and (B and E) current-voltage (I-V) curves are shown before (-) and

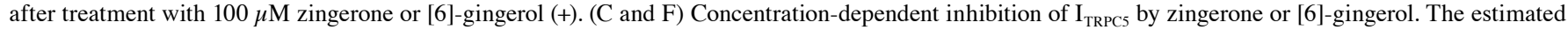
median inhibitory concentration value for zingerone or [6]-gingerol was 6330.7 or $4130.6 \mu \mathrm{M}$. (n=8/group).

were perfused at $3 \mathrm{ml} / \mathrm{min}$. Patch pipettes were pulled from thin-walled borosilicate glass (World Precision Instruments, Sarasota, FL, USA) using a horizontal Flaming Brown P-1000 micropipette puller (Shutter Instruments, Novato, CA, USA). Pipette tips were fire-polished to a resistance of 2-3 M $\Omega$ to facilitate gigaseal formation (Narishige, Tokyo, Japan). Junction potentials were adjusted prior to and pipette capacitances were compensated for electronically following gigaseal formation. Data were saved on a desktop computer and analyzed using Clampfit v.10.4 (Molecular Devices), Prism v.6.0 (GraphPad, La Jolla, CA, USA), and Origin v.8.0 (Microcal, Northampton, MA, USA) software. GTP $\gamma \mathrm{S}$ was dissolved in DMSO to produce a $1 \mathrm{~mol} / 1$ stock solution, which was added to the pipette solution at a final concentration of $0.2 \mathrm{mmol} / \mathrm{l}$ on the day of the experiment to activate G-proteins.

Statistical analysis. Results are expressed as the means \pm standard errors of mean (SEM). $\mathrm{N}$ values refer to the number of separate cells examined. Multiple comparison testing was performed by one-way ANOVA with Bonferroni's post hoc comparison. P-values of $<0.05$ were considered to indicate statistically significant differences.

\section{Results}

Effects of ginger extract and its pungent constituents on TRPC5 channels. TRPC5 is activated by the stimulation of endogenous G-proteins by $\mathrm{G}$ protein coupled receptor (GPCR, e.g., muscarinic receptor hnd histamine receptor) or GTP $\gamma \mathrm{S}$. To determine whether activated G-proteins activate TRPC5 in 293 cells stably expressing mTRPC5, GTP $\gamma \mathrm{S}(0.2 \mathrm{mM})$ was added to the intracellular solution. Whole cell currents were recorded using patch clamp techniques. Initially, whole cell currents were recorded under normal Tyrode's solution. In order to obtain current-voltage (I-V) relationships, we applied a ramp pulse from +100 to $-100 \mathrm{mV}$ for $500 \mathrm{msec}$. In 293 cells stably expressing mTRPC5, TRPC5 currents ( $\left.\mathrm{I}_{\text {TRPC5 }}\right)$ were activated by applying GTP $\gamma \mathrm{S}$ intracellularly. When the external solution was changed from normal Tyrode's solution to $140 \mathrm{mM}$ extracellular bath $\mathrm{Cs}^{+}$solution, $\mathrm{I}_{\mathrm{TRPC} 5}$ at $-100 \mathrm{mV}$ was increased (Fig. 2A). Therefore, $\mathrm{I}_{\mathrm{TRPC} 5}$ currents were induced repeatedly by applying external $\mathrm{Cs}^{+}$in the presence of $0.2 \mathrm{mM}$ GTP $\gamma \mathrm{S}$ in the pipette solution (Fig. 2A). The I-V relationship in the presence of $140 \mathrm{mM}$ external $\mathrm{Cs}^{+}$exhibited a typical doubly rectifying shape (Fig. 2B), and the second $\mathrm{Cs}^{+}$-induced 

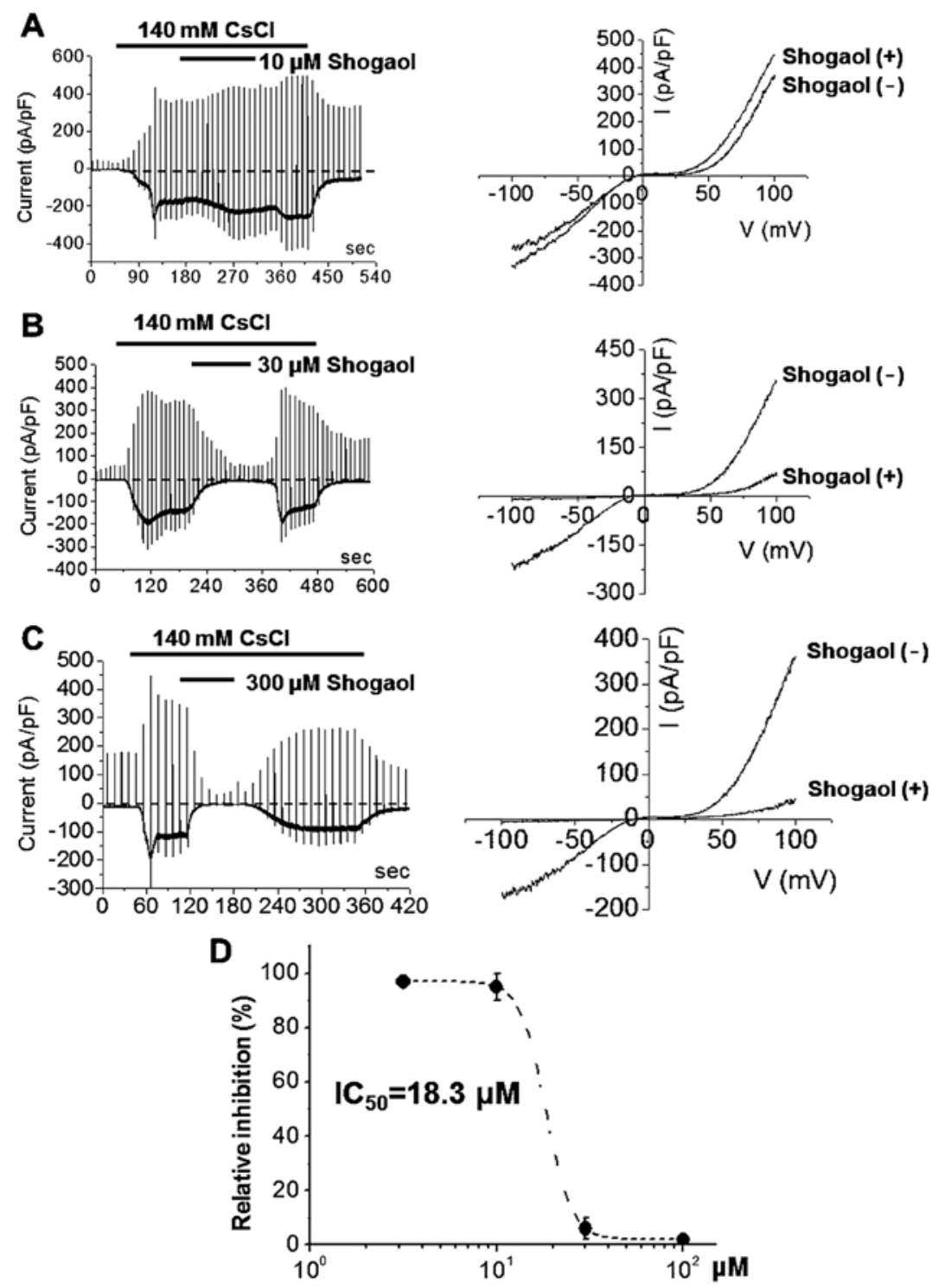

Figure 4. Inhibition of transient receptor potential canonical 5 (TRPC5) by [6]-shogaol. (A-C) Representative traces showing the $\mathrm{I}_{\mathrm{TRPC}}$ evoked in the presence of (A) $10 \mu \mathrm{M}$, (B) $30 \mu \mathrm{M}$ and (C) $300 \mu \mathrm{M}$ [6]-shogaol in 293 cells stably expressing TRPC5. Current-voltage (I-V) curve for control (-) and inhibition of $\mathrm{I}_{\mathrm{TRPC}}$ evoked by [6]-shogaol (+) are shown to the right of each trace. (D) Concentration-dependent inhibition of $\mathrm{I}_{\mathrm{TRPC} 5}$ by [6]-shogaol. The estimated median inhibitory concentration value for [6]-shogaol was $18.3 \mu \mathrm{M}$ (n=8-10/group).

$\mathrm{I}_{\mathrm{TRPC} 5}$ was of similar amplitude to the first (Fig. 2A). Ginger extract inhibited $\mathrm{I}_{\mathrm{TRPC} 5}$ currents in a concentration-dependent manner (Fig. 2A). After washing out the ginger extract, $\mathrm{Cs}^{+}$ activated $\mathrm{I}_{\mathrm{TRPC} 5}$ currents, which showed a typical doubly rectifying shape (Fig. 2B). Ginger extract effectively inhibited $\mathrm{I}_{\mathrm{TRPC} 5}$ currents with an $\mathrm{IC}_{50}$ value of $144.7 \mu \mathrm{g} / \mathrm{ml}$ (Fig. 2C). In order to identify the components of ginger extract responsible for $I_{\text {TRPC } 5}$ inhibition, we investigated the effects of the 3 major components of ginger extract, that is, [6]-gingerol, zingerone and [6]-shogaol, using whole-cell patch clamp experiments. Treatment with zingerone or [6]-gingerol at $300 \mu \mathrm{M}$ (Fig. 3) did not inhibit $\mathrm{I}_{\mathrm{TRPC} 5}$. The I-V relationships showed a typical doubly rectifying shape (Fig. 3). However, at high concentrations, zingerone and [6]-gingerol inhibited $\mathrm{I}_{\mathrm{TRPC} 5}$ with $\mathrm{IC}_{50}$ values of $6330.7 \mu \mathrm{M}$ and $4130.6 \mu \mathrm{M}$, respectively (Fig. 3). By contrast, $\mathrm{I}_{\mathrm{TRPC} 5}$ was strongly and dose-dependently inhibited by [6]-shogaol at concentrations of $10 \mu \mathrm{M}$ (Fig. 4A), $30 \mu \mathrm{M}$ (Fig. 4B) or $300 \mu \mathrm{M}$ (Fig. 4C). The I-V relation- ships showed a typical doubly rectifying shape (Fig. 4). [6]-shogaol effectively inhibited $\mathrm{I}_{\mathrm{TRPC} 5}$ with an $\mathrm{IC}_{50}$ value of $\sim 18.3 \mu \mathrm{M}$ (Fig. 4D). These results suggest that [6]-shogaol is the main factor in ginger extract responsible for $\mathrm{I}_{\mathrm{TRPC} 5}$ inhibition. However, ginger extract $(\leq 1 \mathrm{mg} / \mathrm{ml})$ had no effects on TRPM7 currents (data not shown). Similarly, treatment with zingerone, [6]-gingerol, or [6]-shogaol at $300 \mu \mathrm{M}$ had no effect on TRPM7 currents (data not shown). These results indicate that TRPM7 currents are not the main target of ginger extract.

Effects of ginger extract and its pungent constituents on TRPA1 channels. To determine whether ginger extract activates hTRPA1 channels, we obtained whole-cell patch clamp recordings of 293 cells stably expressing TRPA1. After confirming whole-cell patch formation, we applied a ramp-like pulse protocol from -100 to $+100 \mathrm{mV}$ to obtain a current-voltage (I-V) curve from representative traces obtained at each steady-state time-point before [1] and after [2] ginger extract treatment and following 

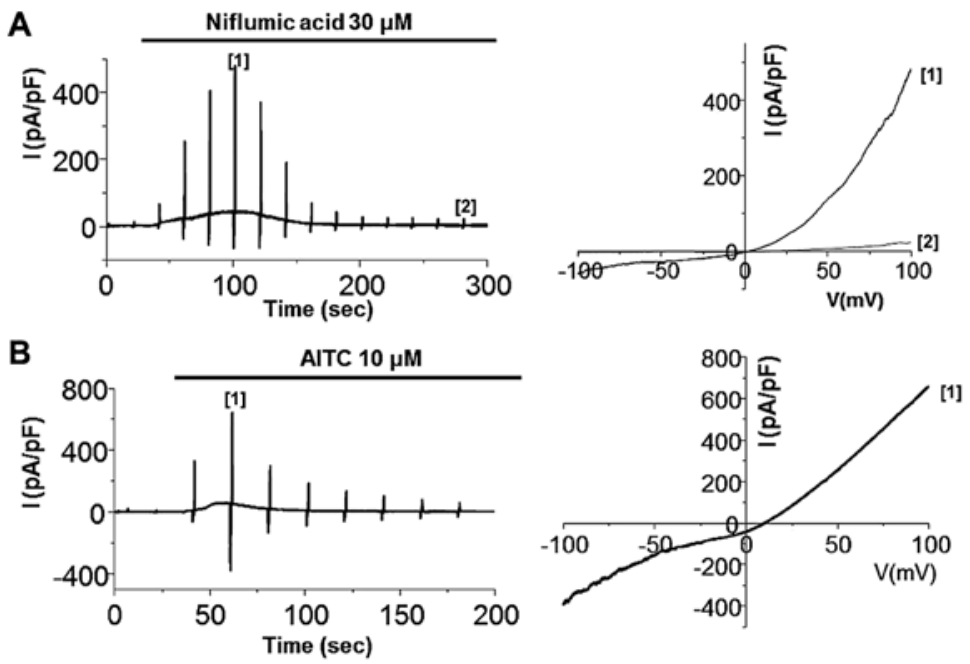

Figure 5. Effects of the known TRPA1 agonists, niflumic acid and allyl isothiocyanate (AITC), on $\mathrm{I}_{\mathrm{TRPA} 1}$. (A) Representative traces and I-V curves of $\mathrm{I}_{\mathrm{TRPA}}$ currents evoked by $30 \mu \mathrm{M}$ niflumic acid in 293 cells stably expressing TRPA1. Recordings for current-voltage (I-V) curves were made of cells treated with niflumic acid [1 and 2]. (B) Representative traces and I-V curves of $\mathrm{I}_{\mathrm{TRPA} 1}$ currents evoked by $10 \mu \mathrm{M}$ AITC in 293 cells stably expressing TRPA1. Recordings for I-V curves were made of treated cell with AITC [1].

treatment with the selective TRPA1 inhibitor, A-967079 [3]. To determine whether TRPA1 channels are functioning well in our transfection system, we performed whole-cell patch clamp with known agonists. The TRPA 1 current $\left(\mathrm{I}_{\mathrm{TRPA} 1}\right)$ has been shown to be activated by AITC, which is the ingredient of mustard, and nonelectrophilic non-steroidal anti-inflammatory drugs (NSAIDs), such as niflumic acid $(19,20)$. As shown in Fig. 5, the bath application of $30 \mu \mathrm{M}$ niflumic acid and $10 \mu \mathrm{M}$ AITC evoked transient current development, demonstrating that the TRPA1 channel is expressed and functional. We then experimented with ginger. $\mathrm{I}_{\mathrm{TRPA} 1}$ was evoked immediately after the application of ginger extract to the bath, demonstrating that the TRPA1 channel was activated by the extract (Fig. 6). The applications of $10 \mu \mathrm{g} / \mathrm{ml}$ (Fig. 6A), $30 \mu \mathrm{g} / \mathrm{ml}$ (Fig. 6B), or $100 \mu \mathrm{g} / \mathrm{ml}$ (Fig. 6C) of ginger extract produced concentration-dependent increases in $\mathrm{I}_{\mathrm{TRPA} 1}$ at both positive and negative potentials. To confirm the stimulatory effects of the extract on TRPA1, the cells were concomitantly treated with A-967079, a selective TRPA1 inhibitor. In the presence of $10 \mu \mathrm{g} / \mathrm{ml}$ of ginger extract, $10 \mu \mathrm{M}$ A-967079 completely abolished $\mathrm{I}_{\mathrm{TRPA} 1}$ (Fig. 6A [3]); however, the currents induced by 30 or $100 \mu \mathrm{g} / \mathrm{ml}$ of extract were not fully inhibited by A-967079 at this concentration (Fig. 6B and C [3]) or even at $30 \mu \mathrm{M}$ (data not shown). The mean current amplitudes evoked at each concentration at $-100 \mathrm{mV}$ are shown in Fig. 6D. On the other hand, pre-treatment of the cells with $30 \mu \mathrm{M}$ A-967079 completely blocked hTRPA1 activation by 30 or $100 \mu \mathrm{g} / \mathrm{ml}$ of ginger extract (Fig. 7). In order to identify the components of ginger extract responsible for the stimulation of $\mathrm{I}_{\mathrm{TRPA} 1}$, we examined the effects of 3 major components of the extract, that is, [6]-gingerol, zingerone and [6]-shogaol, on $\mathrm{I}_{\mathrm{TRPA} 1}$ in whole-cell patch clamp experiments. Treatment of the cells with zingerone or [6]-gingerol at a strong depolarizing potential induced $\mathrm{I}_{\mathrm{TRPA} 1}$; at a concentration of $100 \mu \mathrm{M}$, neither of these compounds produced an inward current, but both induced a slight outward current at potentials over $+50 \mathrm{mV}$ (Fig. 8), which was inhibited by $10 \mu \mathrm{M}$ A-967079. The summarized data of $\mathrm{I}_{\text {TRPA1 }}$ activated by [6]-gingerol or zingerone at -100 and $+100 \mathrm{mV}$ is shown in Fig. 8C and F, respectively. Although the $\mathrm{I}_{\mathrm{TRPA} 1}$ produced at $+100 \mathrm{mV}$ by these two compounds were significant, their effects were weak compared to those of whole ginger extract. By contrast, hTRPA1 was strongly activated in a dose-dependent manner by $10 \mu \mathrm{M}$ (Fig. 9A), $30 \mu \mathrm{M}$ (Fig. 9B), or $100 \mu \mathrm{M}$ (Fig. 9C) of [6]-shogaol, and this effect was abolished by the addition of A-967079 to the bath solution. The mean current amplitudes evoked at the different [6]-shogaol concentrations at -100 and $+100 \mathrm{mV}$ are shown in Fig. 9D. These results suggest that [6]-shogaol is the main factor in ginger extract responsible for $\mathrm{I}_{\mathrm{TRPA} 1}$ activation.

\section{Discussion}

Ginger is a medicinal plant that has been widely used in traditional medicine for the treatment of arthritis, catarrh, rheumatism, nervous diseases, gingivitis, toothache, asthma, stroke, constipation, indigestion, vomiting, hypertension, dementia and diabetes (8,22-24). Ginger is also one of the most commonly used pungents and aromatic spices and adds a special flavor and zest to food $(6,8,25)$. Ginger contains numerous active compounds which vary significantly between plant varieties and geographic regions. More than 60 active constituents are known to be present in ginger. Phytochemical reports have demonstrated that the main constituents of ginger are gingerols, zingerone and shogaols $(26,27)$. [6]-Gingerol and [6]-shogaol are the major gingerol and shogaol present in ginger $(27,28)$. Zingerone is produced during the drying of ginger and by the thermal degradation of gingerols or shogaols (29). The pharmacological actions of ginger and of its component compounds include immunomodulatory, anti-tumorigenic, anti-inflammatory, anti-apoptotic, anti-hyperglycemic, antilipidemic and anti-emetic effects (6-8). In addition, ginger is a potent antioxidant and may mitigate or prevent free radical generation $(2,8,11-13)$.

Several authors have demonstrated that ginger has strong in vitro and in vivo antioxidant properties. The antioxidant action of ginger has been proposed to underlie its protective effects against radiation $(8,30,31)$ and a number of toxic agents, such as 

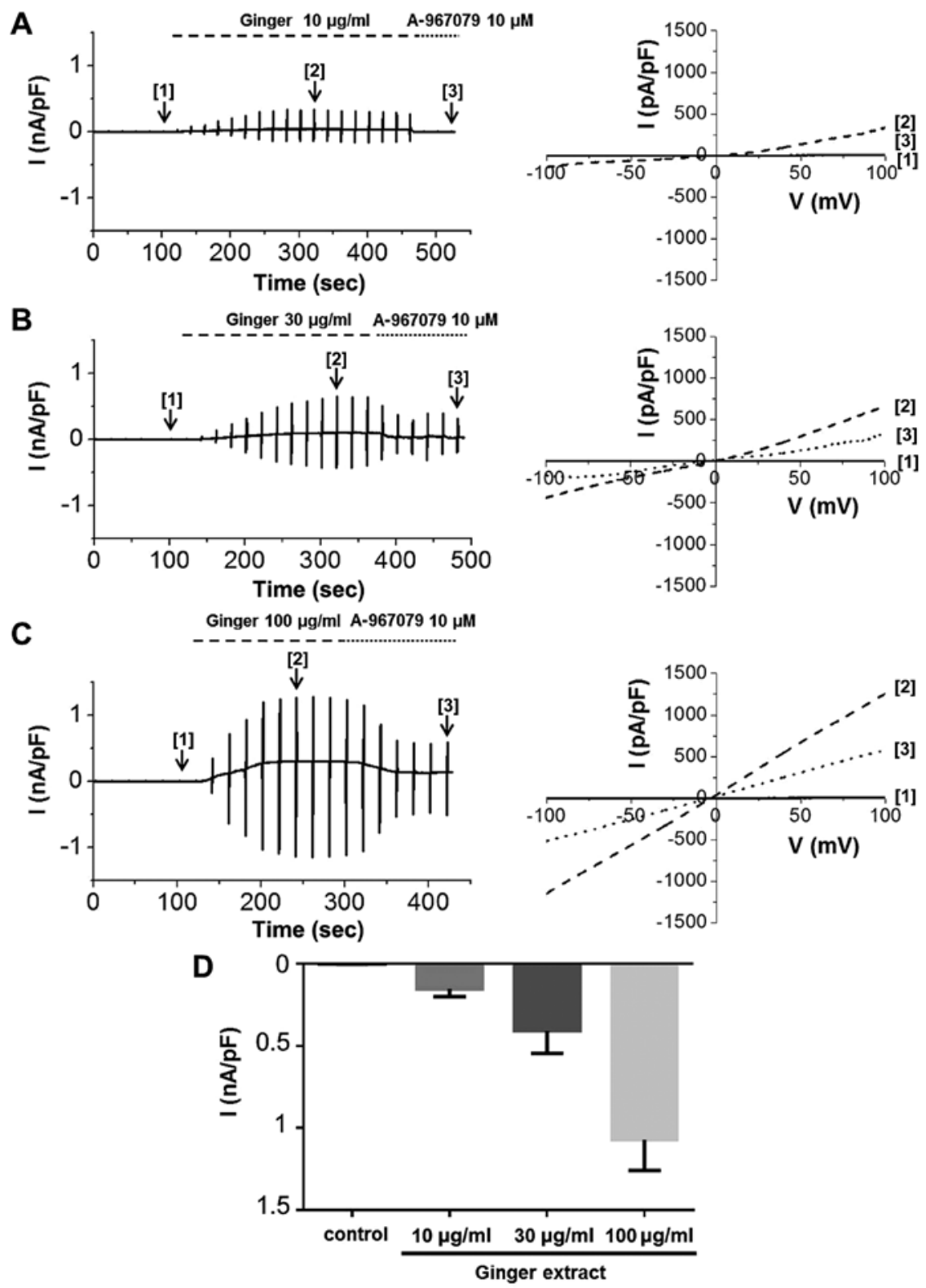

Figure 6. Activation of hTRPA1 by ginger extract. (A-C) Representative traces showing the $\mathrm{I}_{\mathrm{TRPA}}$ currents evoked in the presence of (A) $10 \mu \mathrm{g} / \mathrm{ml}$, (B) $30 \mu \mathrm{g} / \mathrm{ml}$, or (C) $100 \mu \mathrm{g} / \mathrm{ml}$ ginger extract in 293 cells stably expressing TRPA1. Channel activation was confirmed by blocking I $\mathrm{I}_{\text {TRPA } 1}$ with $10 \mu \mathrm{M}$ A-967079. Currentvoltage (I-V) curve for control [1], the steady-state $\mathrm{I}_{\mathrm{TRPA} 1}$ evoked by $10 \mu \mathrm{g} / \mathrm{ml}$ ginger extract [2], and inhibition of the steady-state $\mathrm{I}_{\mathrm{TRPAl}}$ by $10 \mu \mathrm{M}$ A-967079 [3] are shown to the right of each trace. (D) Summary of mean current amplitudes evoked by control (n=25), $10 \mu \mathrm{g} / \mathrm{ml}(\mathrm{n}=8), 30 \mu \mathrm{g} / \mathrm{ml}(\mathrm{n}=9)$, or $100 \mu \mathrm{g} / \mathrm{ml}(\mathrm{n}=8)$ of ginger extract at $-100 \mathrm{mV}$.

carbon tetrachloride and cisplatin $(8,32,33)$, and its efficacy as an anti-ulcer treatment (34). Among its compounds, 6-gingerol is an effective agent at preventing ultra violet B (UVB)-induced ROS production and cyclooxygenase (COX)-2 expression, and therefore, 6-gingerol may have antioxidant effects in vivo, in addition to potent anti-inflammatory and anti-apoptotic effects $(8,35)$. 6-Shogaol effectively scavenges various free radicals in vitro, and displays marked cytoprotective effects against oxidative stress-induced cell damage by activating the Nrf2 gene in a neuron-like rat pheochromocytoma cell line (PC12 cells) (2).

Ion channels play critical roles during essential physiological functions, such as muscle contraction, hormone secretion and neuroprotection (36), and ion channel defects lead to a variety of diseases, including cancer $(37,38)$. Previous studies have revealed that TRP channels are associated with cell proliferation, apoptosis and cancer development $(39,40)$. These channels are NSCCs, and were initially cloned from Drosophila melanogaster. All TRP channels possess putative six-transmembrane spanning domains. The various gating mechanisms of TRP channels play crucial roles in their pathologic and physiologic functions (41-44). Recent studies have revealed that multiple TRP channels sense reactive species and induce diverse physiological and pathological responses, such as cell death, chemokine production and pain transduction (45). TRP channels sense reactive species either indirectly through second messengers or directly via oxidative modification of cysteine residues. The redox-sensitive TRP channels are TRPC5, TRPM7, TRPA1, TRPV1 and TRPM2 (45). TRPC5 is directly activated by $\mathrm{H}_{2} \mathrm{O}_{2}$ and the NO donor, S-nitroso-Nacetyl-DL-penicillamine, via cysteine modification (46). In 
A

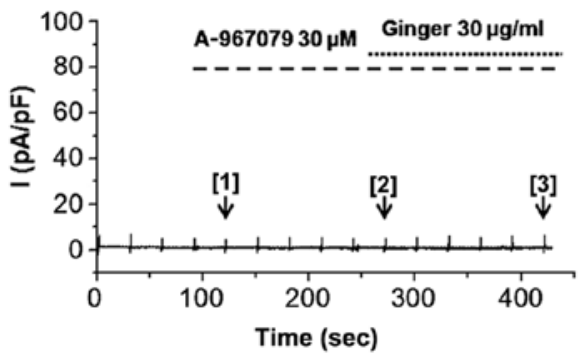

B

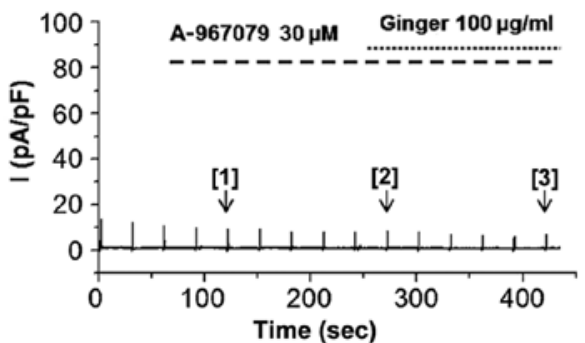

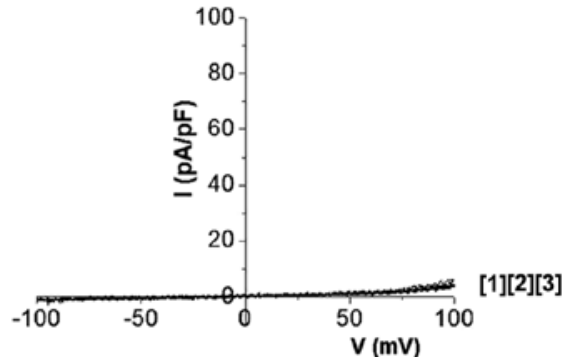

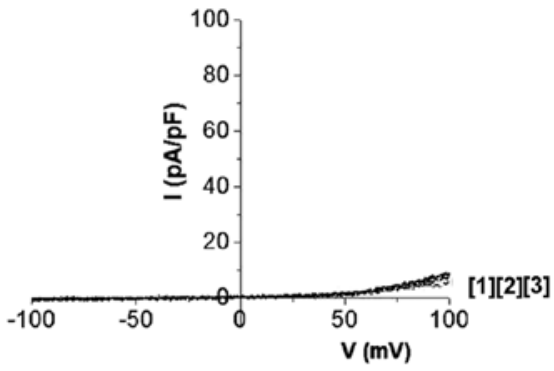

Figure 7. hTRPA1 activation by ginger extract was blocked by pre-treatment with A-967069. (A and B) Representative traces and current-voltage (I-V) curves of $\mathrm{I}_{\mathrm{TRPA} 1}$ currents evoked by (A) $30 \mu \mathrm{g} / \mathrm{ml}$ or (B) $100 \mu \mathrm{g} / \mathrm{ml}$ ginger extract in 293 cells stably expressing TRPA1. Cells were treated with $30 \mu \mathrm{M}$ A-967079 2 min prior to adding extract. Recordings for I-V curves were made of untreated cells (control 1), cells treated with $30 \mu \mathrm{M}$ A-967069 (control 2), and cells treated with ginger extract following treatment with $30 \mu \mathrm{M}$ A-967069 (control 3). Experiments were repeated 3 times.
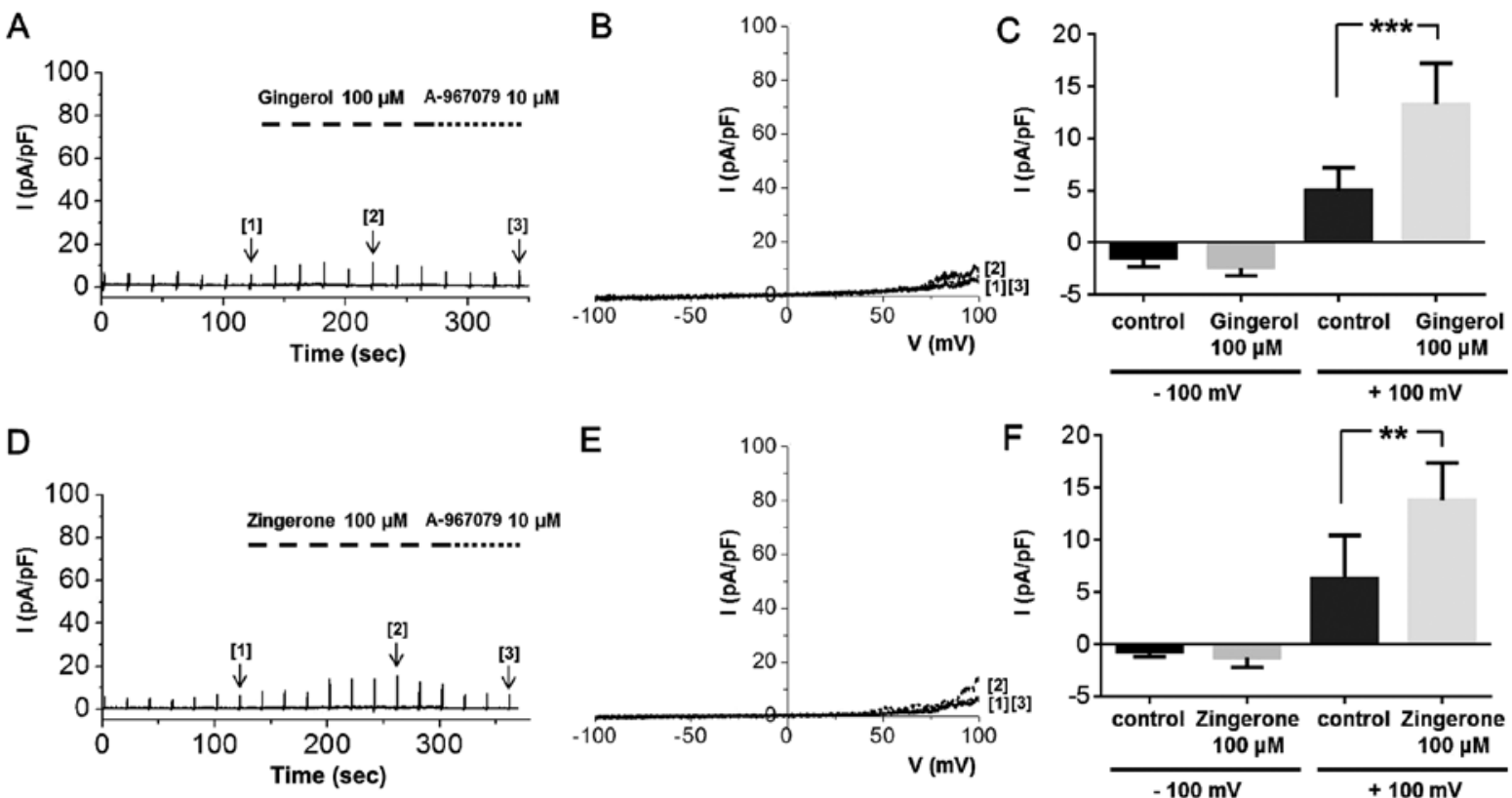

Figure 8. Effect of [6]-gingerol and zingerone on $\mathrm{I}_{\mathrm{TRPA} 1}$. Effect of treatment wiht (A-C) $100 \mu \mathrm{M}$ [6]-gingerol and (D-F) zingerone on $\mathrm{I}_{\mathrm{TRPA} 1}$ currents in 293 cells stably expressing TRPA1. (A and D) Representative traces and (B and E) I-V curves of cells are shown of untreated cells (control 1), cells treated with $100 \mu \mathrm{M}$ [6]-gingerol or zingerone (control 2), and cells treated with $100 \mu \mathrm{M}$ [6]-gingerol or zingerone after $10 \mu \mathrm{M} \mathrm{A}-967069$ pretreatment (control 3). (C and F) Summary of the mean peak $\mathrm{I}_{\mathrm{TRPA} 1}$ currents at -100 and $+100 \mathrm{mV}$ at each time point. ${ }^{* *} \mathrm{P}<0.01$ and ${ }^{* * * *} \mathrm{P}<0.001$ vs. the untreated control (n=5/group).

endothelial cells, native TRPC5 is likely to be activated by NO generated by endothelial-type NO synthase (18). The redox modification of cysteine residue sulfhydryl groups has emerged as an important elementary step in the signal transduction cascades that underlie many physiological responses (47). In a previous study, NO-activated TRPC5 channels were significantly, but not entirely suppressed by ascorbate, which reduces $\mathrm{S}$-nitrosothiols (but not disulfides) to thiols, but dithiothreitol (DTT), which reduces both S-nitrosothiols and disulfides to thiols, fully suppressed NO-activated TRPC5 channel activity (45). The authors suggested that both nitrosylation and disulfide bond formation are likely to be involved in NO-induced TRPC5 activation (45). ROS and RNS can serve as activators of cation conductance through TRPM7, and thus contribute to anoxic neuronal death (17). It has been proposed that during the oxygen or glucose deprivation of primary cortical neurons, a $\mathrm{Ca}^{2+}$-permeable non-selective cation conductance mediated by TRPM7 is activated by ROS/ RNS and is primarily responsible for neuronal death (17). This is supported by the observation that ROS/RNS are able 

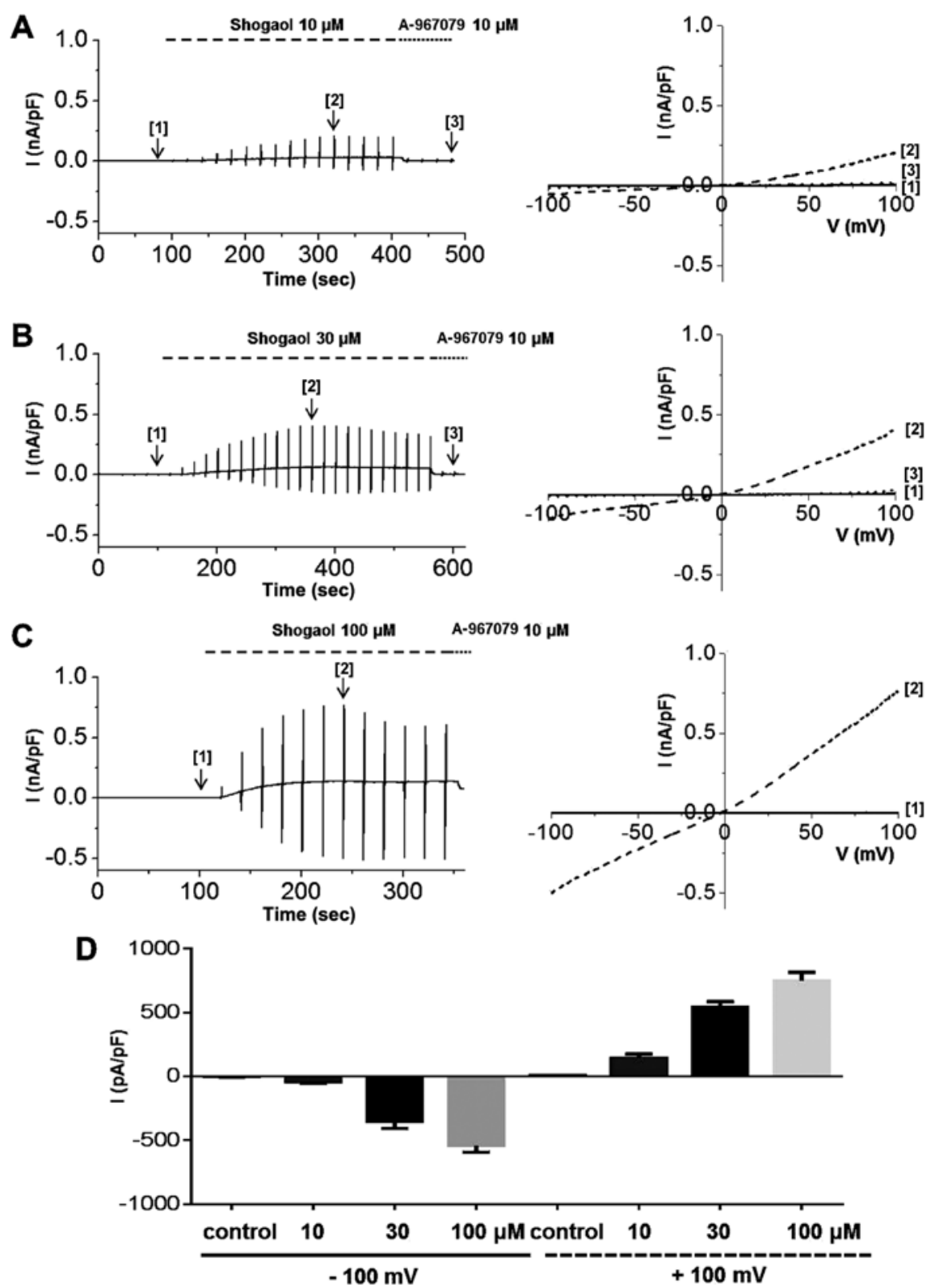

Figure 9. Activation of hTRPA1 by [6]-shogaol. (A-C) Representative traces showing the $\mathrm{I}_{\mathrm{TRPA}}$ currents evoked in the presence of (A) $10 \mu \mathrm{M}$, (B) $30 \mu \mathrm{M}$ or (C) $100 \mu \mathrm{M}$ [6]-shogaol in 293 cells stably expressing TRPA1. Channel activation was confirmed by blocking $\mathrm{I}_{\text {TRPAl }}$ with $10 \mu \mathrm{M}$ A-967079. Currentvoltage (I-V) curve for the untreated control [1], steady-state $\mathrm{I}_{\mathrm{TRPA}}$ evoked by $10 \mu \mathrm{M}$ [6]-shogaol [2], and inhibition of the steady-state $\mathrm{I}_{\mathrm{TRPAI}}$ evoked by $10 \mu \mathrm{M}$ [6]-shogaol by $10 \mu \mathrm{M}$ A-967079 pre-treatment [3] are shown to the right of each trace. (D) Summary of mean current amplitudes evoked in untreated control cells $(\mathrm{n}=33)$ and in $10 \mu \mathrm{M}(\mathrm{n}=10), 30 \mu \mathrm{M}(\mathrm{n}=10)$, or $100 \mu \mathrm{M}(\mathrm{n}=9)$ [6]-shogaol-treated cells at -100 and $+100 \mathrm{mV}$.

to enhance TRPM7-mediated inward currents in TRPM7transfected 293 cells. In addition, in primary neurons, it appears that the electrophysiological properties of currents activated by oxygen- and glucose deprivation, including currents enhanced by low $\mathrm{Mg}^{2+}$ and inhibited by high $\mathrm{Mg}^{2+}$, are characteristic of TRPM7 and are not shared by TRPM2 (17). Furthermore, the suppression of TRPM7 expression in primary cortical neurons blocked TRPM7 currents, $\mathrm{Ca}^{2+}$ influx and ROS production, protecting cells from anoxic cell death $(17,45)$. TRPA1 is also modified via oxidative cysteine modification by ROS and RNS. TRPA1 is activated by ROS/RNS, such as, hypochlorite $\left(\mathrm{OCl}^{-}\right)(48), \mathrm{H}_{2} \mathrm{O}_{2}(19)$, $\mathrm{NO}(19)$, ozone $\left(\mathrm{O}_{3}\right)(49)$ and

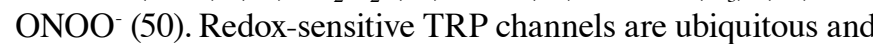
participate in ROS-dependent cellular functions, including cell death, chemokine production and ROS detection, but novel roles are emerging in the contexts of ischemia/reperfusion, neurodegeneration, mental illness, vascular hyperpermeability and itch sensation (51-54). Considering the ubiquitous nature of TRP channels and ROS/RNS production, it is conceivable that TRP channel redox sensitivity may also participate in other as yet unidentified biological phenomena. Thus, the characterization of the in vivo functions of ROS-sensitive TRP channels under physiological and pathological conditions is a fertile field for exploration (45).

In the present study, we investigated the effects of ginger and its pungent constituents on the redox-sensitive TRP channels, TRPC5, TRPM7 and TRPA1 and, to the best of our knowledge, present the results of the first electrophysiological study 
undertaken to explore the modulatory effects of ginger and some of its constituents on these TRP channels. Using wholecell patch-clamp recordings, we found that TRPC5 and TRPA1 currents were modulated by ginger extract and by [6]-gingerols, zingerone and [6]-shogaols. Above all, [6]-shogaol markedly inhibited TRPC5 currents in a dose-dependent manner with an $\mathrm{IC}_{50}$ value of $\sim 18.3 \mu \mathrm{M}$. On the other hand, [6]-shogaol strongly activated TRPA1 currents in a dose-dependent manner and its effect was abolished by the addition of A-967079 (a selective TRPA1 inhibitor). However, ginger extract, [6]-gingerols, zingerone and [6]-shogaols, had no effects on TRPM7 currents. Therefore, it seems that [6]-shogaol plays an important role in the regulation of TRPC5 and TRPA1 currents. However, there was no direct investigation of the effects of the ginger extract components on the oxidant-induced ion channel current changes and therefore, these results are only the pharmacological effects of ginger and its pungent constituents on the variety of TRP channels. In the future in further investigations, we aim to apply these results on oxidant-induced ion channels on single cells from tissues.

[6]-Shogaol is one of the phenolic alkanones isolated from ginger that exhibits significant anti-proliferative activity in various cancer cell lines $(55,56)$. In addition, [6]-shogaol induces cell death through oxidative stress-mediated caspase activation (57). In particular, [6]-shogaol has been reported to induce the apoptosis of human colorectal carcinoma cells via ROS production and caspase activation (58). In addition, [6]-shogaol has been shown to induce autophagy in human non-small cell lung cancer A549 cells by inhibiting the Akt/ mTOR pathway (55). Although a number of studies have addressed the activity of [6]-shogaol, in this study, we suggest that [6]-shogaol has potent antioxidant effects on TRP channels. In addition, $[6,8,10]$-shogaols have differences in the length of the alkyl carbon chain and increased intracellular $\mathrm{Ca}^{2+}$ concentration in rat TRPV1-expressing 293 cells. In this regard, shogaols are more potent than gingerols (59). Both [6]-gingerol and [8]-gingerol evoke capsaicin-like $\mathrm{Ca}^{2+}$ transients and ion currents in DRG neurons, with both effects being sensitive to the action of capsazepine (60). Aversive responses were shown to be induced by [6]- and [10]-gingerol, and [6]-shogaol in rats when these compounds were applied to the eyes; however, no response was observed in response to [10]-shogaol. [10]-Shogaol induced nociceptive responses via TRPV1 in rats following its subcutaneous injection into the hindpaw (61, and refs. therein). In addition, [6]-shogaol induces $\mathrm{Ca}^{2+}$ signals in $\beta$-cells by activating the TRPV1 channels, and it sensitizes $\beta$-cells to stimulation by glucose (62). Therefore, gingerols and shogaols function as activators of the TRPV1 channel. Furthermore, the effects of shogaol may be the electrophilic conjugation to the thiol residues of the tested TRP channels. The chemical structure of shogaol (Fig. 1) shows an electrophilic $\alpha$ - $\beta$-unsaturated carbonyl group, which may produce Michael adduct formation with the channels. As the same mechanism responses on ion channels as shogaol, there are curcumin and caffeic acid phenethyl ester (CAPE). Curcumin and CAPE have been shown to inhibit $\mathrm{Ca}^{2+}$ release-activated $\mathrm{Ca}^{2+}$ channel (CRAC) current in Orai1/STIM1-co-expressing 293 cells $(63,64)$ and the electrophilic addition to the Orail 195Cys was responsible for the inhibitory effect of $\mathrm{Ca}^{2+}$ release-activated $\mathrm{Ca}^{2+}$ current by curcumin and CAPE (65).
Taken together, the findings of our study suggest that ginger extract exerts antioxidant effects on TRPC5 and TRPA1 channels, and that its pungent constituent, [6]-shogaol is primarily responsible for the regulation of TRPC5 and TRPA1 currents. In view of the effects of the redox sensitivity of TRP channels on various pathological and biological phenomena, future studies are warranted to confirm that TRP channel regulation by ginger and its pungent constituents is of pharmacological importance in vivo.

\section{Acknowledgements}

The present study was supported by the a Korean National Research Foundation (NRF) grant funded by the Korea Government (MSIP) (no. 2014R1A5A2009936)

\section{References}

1. Stoll EA, Cheung W, Mikheev AM, Sweet IR, Bielas JH, Zhang J, Rostomily RC and Horner PJ: Aging neural progenitor cells have decreased mitochondrial content and lower oxidative metabolism. J Biol Chem 286: 38592-38601, 2011.

2. Peng S, Yao J, Liu Y, Duan D, Zhang X and Fang J: Activation of Nrf2 target enzymes conferring protection against oxidative stress in PC12 cells by ginger principal constituent 6-shogaol. Food Funct 6: 2813-2823, 2015.

3. Campos PB, Paulsen BS and Rehen SK: Accelerating neuronal aging in in vitro model brain disorders: A focus on reactive oxygen species. Front Aging Neurosci 6: 292, 2014.

4. Palatty PL, Haniadka R, Valder B, Arora R and Baliga MS: Ginger in the prevention of nausea and vomiting: A review. Crit Rev Food Sci Nutr 53: 659-669, 2013.

5. Haniadka R, Saldanha E, Sunita V, Palatty PL, Fayad R and Baliga MS: A review of the gastroprotective effects of ginger (Zingiber officinale Roscoe). Food Funct 4: 845-855, 2013.

6. Chrubasik S, Pittler MH and Roufogalis BD: Zingiberis rhizoma: A comprehensive review on the ginger effect and efficacy profiles. Phytomedicine 12: 684-701, 2005.

7. Shukla Y and Singh M: Cancer preventive properties of ginger: A brief review. Food Chem Toxicol 45: 683-690, 2007.

8. Ali BH, Blunden G, Tanira MO and Nemmar A: Some phytochemical, pharmacological and toxicological properties of ginger (Zingiber officinale Roscoe): A review of recent research. Food Chem Toxicol 46: 409-420, 2008.

9. Govindarajan VS and Connell DW: Ginger - chemistry, technology, and quality evaluation: Part 1. Crit Rev Food Sci Nutr 17: 1-96, 1982.

10. Govindarajan VS and Connell DW: Ginger-chemistry, technology, and quality evaluation: Part 2. Crit Rev Food Sci Nutr 17: 189-258, 1982.

11. Mohamed OI, El-Nahas AF, El-Sayed YS and Ashry KM: Ginger extract modulates $\mathrm{Pb}$-induced hepatic oxidative stress and expression of antioxidant gene transcripts in rat liver. Pharm Biol 16: 1-9, 2015.

12. Khaki A, Khaki AA, Hajhosseini L, Golzar FS and Ainehchi N: The anti-oxidant effects of ginger and cinnamon on spermatogenesis dys-function of diabetes rats. Afr J Tradit Complement Altern Medicines 11: 1-8, 2014.

13. Fu J, Chen H, Soroka DN, Warin RF and Sang S: Cysteineconjugated metabolites of ginger components, shogaols, induce apoptosis through oxidative stress-mediated p53 pathway in human colon cancer cells. J Agric Food Chem 62: 4632-4642, 2014.

14. Park HS, Hong C, Kim BJ and So I: The pathophysiologic roles of TRPM7 channel. Korean J Physiol Pharmacol 18: 15-23, 2014.

15. Hara Y, Wakamori M, Ishii M, Maeno E, Nishida M, Yoshida T, Yamada H, Shimizu S, Mori E, Kudoh J, et al: LTRPC2 $\mathrm{Ca}^{2+}$-permeable channel activated by changes in redox status confers susceptibility to cell death. Mol Cell 9: 163-173, 2002.

16. Yamamoto S, Shimizu S, Kiyonaka S, Takahashi N, Wajima T, Hara Y, Negoro T, Hiroi T, Kiuchi Y, Okada T, et al: TRPM2mediated $\mathrm{Ca}^{2+}$ influx induces chemokine production in monocytes that aggravates inflammatory neutrophil infiltration. Nat Med 14: 738-747, 2008. 
17. Aarts M, Iihara K, Wei WL, Xiong ZG, Arundine M, Cerwinski W, MacDonald JF and Tymianski M: A key role for TRPM7 channels in anoxic neuronal death. Cell 115: 863-877, 2003.

18. Yoshida T, Inoue R, Morii T, Takahashi N, Yamamoto S, Hara Y, Tominaga M, Shimizu S, Sato Y and Mori Y: Nitric oxide activates TRP channels by cysteine S-nitrosylation. Nat Chem Biol 2: 596-607, 2006.

19. Takahashi N, Mizuno Y, Kozai D, Yamamoto S, Kiyonaka S, Shibata T, Uchida K and Mori Y: Molecular characterization of TRPA1 channel activation by cysteine-reactive inflammatory mediators. Channels (Austin) 2: 287-298, 2008.

20. Andersson DA, Gentry C, Moss S and Bevan S: Transient receptor potential A1 is a sensory receptor for multiple products of oxidative stress. J Neurosci 28: 2485-2494, 2008.

21. Macpherson LJ, Dubin AE, Evans MJ, Marr F, Schultz PG, Cravatt $\mathrm{BF}$ and Patapoutian A: Noxious compounds activate TRPA1 ion channels through covalent modification of cysteines Nature 445: 541-545, 2007.

22. Awang DVC: Ginger. Can Pharm J 125: 309-311, 1992.

23. Wang WH and Wang ZM: Studies of commonly used traditional medicine-ginger. Zhongguo Zhong Yao Za Zhi 30: 1569-1573, 2005 (In Chinese)

24. Tapsell LC, Hemphill I, Cobiac L, Patch CS, Sullivan DR, Fenech M, Roodenrys S, Keogh JB, Clifton PM, Williams PG, et al: Health benefits of herbs and spices: The past, the present, the future. Med J Aust 185 (Suppl): S4-S24, 2006.

25. Afzal M, Al-Hadidi D, Menon M, Pesek J and Dhami MS Ginger: An ethnomedical, chemical and pharmacological review. Drug Metabol Drug Interact 18: 159-190, 2001.

26. Langner E, Greifenberg $S$ and Gruenwald J: Ginger: History and use. Adv Ther 15: 25-44, 1998.

27. Ghayur MN, Gilani AH, Afridi MB and Houghton PJ: Cardiovascular effects of ginger aqueous extract and its phenolic constituents are mediated through multiple pathways. Vascul Pharmacol 43: 234-241, 2005.

28. Connell DW and McLachlan R: Natural pungent compounds: Examination of gingerols, shogaols, paradols and related compounds by thin-layer and gas chromatography. J Chromatogr A 67: 29-35, 1972.

29. Ahmad B, Rehman MU, Amin I,Arif A, Rasool S, Bhat SA, Afzal I, Hussain I, Bilal S, and Mir Mu: A review on pharmacological properties of zingerone (4-(4-hydroxy-3-methoxyphenyl)-2butanone). ScientificWorldJournal 2015: 816364, 2015.

30. Jagetia GC, Baliga MS, Venkatesh P and Ulloor JN: Influence of ginger rhizome (Zingiber officinale Rosc) on survival, glutathione and lipid peroxidation in mice after whole-body exposure to gamma radiation. Radiat Res 160: 584-592, 2003.

31. Haksar A, Sharma A, Chawla R, Kumar R, Arora R, Singh S, Prasad J, Gupta M, Tripathi RP, Arora MP, et al: Zingiber officinale exhibits behavioral radioprotection against radiationinduced CTA in a gender-specific manner. Pharmacol Biochem Behav 84: 179-188, 2006

32. Amin A and Hamza AA: Effects of Roselle and Ginger on cisplatin-induced reproductive toxicity in rats. Asian J Androl 8 607-612, 2006

33. Yemitan OK and Izegbu MC: Protective effects of Zingiber officinale (Zingiberaceae) against carbon tetrachloride and acetaminophen-induced hepatotoxicity in rats. Phytother Res 20 : 997-1002, 2006

34. Siddaraju MN and Dharmesh SM: Inhibition of gastric $\mathrm{H}^{+}$ $\mathrm{K}^{+}$-ATPase and Helicobacter pylori growth by phenolic antioxidants of Zingiber officinale. Mol Nutr Food Res 51: 324-332, 2007

35. Kim JK, Kim Y, Na KM, Surh YJ and Kim TY: [6]-Gingerol prevents UVB-induced ROS production and COX-2 expression in vitro and in vivo. Free Radic Res 41: 603-614, 2007.

36. Doyle JL and Stubbs L: Ataxia, arrhythmia and ion-channel gene defects. Trends Genet 14: 92-98, 1998.

37. Kunzelmann K: Ion channels and cancer. J Membr Biol 205: 159-173, 2005

38. Pardo LA: Voltage-gated potassium channels in cell proliferation Physiology (Bethesda) 19: 285-292, 2004.

39. Schwarz EC, Wissenbach U, Niemeyer BA, Strauss B, Philipp SE, Flockerzi V and Hoth M: TRPV6 potentiates calcium-dependent cell proliferation. Cell Calcium 39: 163-173, 2006.

40. Bödding M: TRP proteins and cancer. Cell Signal 19: 617-624, 2007.

41. Clapham DE: TRP channels as cellular sensors. Nature 426: 517-524, 2003

42. Pedersen SF, Owsianik G and Nilius B: TRP channels: An overview. Cell Calcium 38: 233-252, 2005
43. Ramsey IS, Delling M and Clapham DE: An introduction to TRP channels. Annu Rev Physiol 68: 619-647, 2006.

44. Nilius B and Owsianik G: The transient receptor potential family of ion channels. Genome Biol 12: 218, 2011.

45. Kozai D, Ogawa N and Mori Y: Redox regulation of transient receptor potential channels. Antioxid Redox Signal 21: 971-986, 2014.

46. Takahashi $\mathrm{N}$ and Mori Y: TRP channels as sensors and signal integrators of redox status changes. Front Pharmacol 2: 58, 2011

47. Bindoli A and Rigobello MP: Principles in redox signaling: From chemistry to functional significance. Antioxid Redox Signal 18 1557-1593, 2013.

48. Bessac BF, Sivula M, von Hehn CA, Escalera J, Cohn L and Jordt SE: TRPA1 is a major oxidant sensor in murine airway sensory neurons. J Clin Invest 118: 1899-1910, 2008.

49. Taylor-Clark TE and Undem BJ: Ozone activates airway nerves via the selective stimulation of TRPA1 ion channels. J Physiol 588: 423-433, 2010.

50. Sawada Y, Hosokawa H, Matsumura K and Kobayashi S: Activation of transient receptor potential ankyrin 1 by hydrogen peroxide. Eur J Neurosci 27: 1131-1142, 2008.

51. Hecquet CM, Ahmmed GU, Vogel SM and Malik AB: Role of TRPM2 channel in mediating $\mathrm{H}_{2} \mathrm{O}_{2}$-induced $\mathrm{Ca}^{2+}$ entry and endothelial hyperpermeability. Circ Res 102: 347-355, 2008.

52. Hiroi T, Wajima T, Negoro T, Ishii M, Nakano Y, Kiuchi Y, Mori Y and Shimizu S: Neutrophil TRPM2 channels are implicated in the exacerbation of myocardial ischaemia/reperfusion injury. Cardiovasc Res 97: 271-281, 2013.

53. Liu T and Ji RR: Oxidative stress induces itch via activation of transient receptor potential subtype ankyrin 1 in mice. Neurosci Bull 28: 145-154, 2012.

54. Roedding AS, Gao AF, Au-Yeung W, Scarcelli T, Li PP and Warsh JJ: Effect of oxidative stress on TRPM2 and TRPC3 channels in B lymphoblast cells in bipolar disorder. Bipolar Disord 14: 151-161, 2012.

55. Hung JY, Hsu YL, Li CT, Ko YC, Ni WC, Huang MS and Kuo PL: 6-Shogaol, an active constituent of dietary ginger, induces autophagy by inhibiting the AKT/mTOR pathway in human non-small cell lung cancer A549 cells. J Agric Food Chem 57: 9809-9816, 2009.

56. Weng CJ, Wu CF, Huang HW, Ho CT and Yen GC: Anti-invasion effects of 6-shogaol and 6-gingerol, two active components in ginger, on human hepatocarcinoma cells. Mol Nutr Food Res 54: 1618-1627, 2010.

57. Chen CY, Liu TZ, Liu YW, Tseng WC, Liu RH, Lu FJ, Lin YS, Kuo SH and Chen CH: 6-shogaol (alkanone from ginger) induces apoptotic cell death of human hepatoma p53 mutant Mahlavu subline via an oxidative stress-mediated caspase-dependent mechanism. J Agric Food Chem 55: 948-954, 2007.

58. Hu R, Zhou P, Peng YB, Xu X, Ma J, Liu Q, Zhang L, Wen XD, Qi LW, Gao N and Li P: 6-Shogaol induces apoptosis in human hepatocellular carcinoma cells and exhibits anti-tumor activity in vivo through endoplasmic reticulum stress. PLoS One 7: e39664, 2012.

59. Iwasaki Y,Morita A,Iwasawa T, KobataK, Sekiwa Y, Morimitsu Y, Kubota $\mathrm{K}$ and Watanabe T: A nonpungent component of steamed ginger - [10]-shogaol - increases adrenaline secretion via the activation of TRPV1. Nutr Neurosci 9: 169-178, 2006.

60. Dedov VN, Tran VH, Duke CC, Connor M, Christie MJ, Mandadi S and Roufogalis BD: Gingerols: A novel class of vanilloid receptor (VR1) agonists. Br J Pharmacol 137: 793-798, 2002.

61. Vriens J, Nilius B and Vennekens R: Herbal compounds and toxins modulating TRP channels. Curr Neuropharmacol 6: 79-96, 2008.

62. Rebellato P and Islam MS: [6]-shogaol induces $\mathrm{Ca}^{2+}$ signals by activating the TRPV1 channels in the rat insulinoma INS-1E cells. JOP 15: 33-37, 2014

63. Nam JH, Shin DH, Zheng H, Kang JS, Kim WK and Kim SJ: Inhibition of store-operated $\mathrm{Ca}^{2+}$ entry channels and $\mathrm{K}^{+}$ channels by caffeic acid phenethylester in T lymphocytes. Eur J Pharmacol 612: 153-160, 2009.

64. Shin DH, Seo EY, Pang B, Nam JH, Kim HS, Kim WK and Kim SJ: Inhibition of $\mathrm{Ca}^{2+}$-release-activated $\mathrm{Ca}^{2+}$ channel (CRAC) and $\mathrm{K}^{+}$channels by curcumin in Jurkat-T cells. J Pharmacol Sci 115: 144-154, 2011 .

65. Shin DH, Nam JH, Lee ES, Zhang Y and Kim SJ: Inhibition of $\mathrm{Ca}(2+)$ release-activated $\mathrm{Ca}(2+)$ channel (CRAC) by curcumin and caffeic acid phenethyl ester (CAPE) via electrophilic addition to a cysteine residue of Orail. Biochem Biophys Res Commun 428: 56-61, 2012. 